\title{
Instructor Social Presence and Connectedness in a Quick Shift from Face-to-Face to Online Instruction
}

\author{
Sheri Conklin and Amy Garrett Dikkers \\ University of North Carolina Wilmington
}

\begin{abstract}
During the first weeks of the COVID-19 pandemic, instructors at a southeastern university had one week to convert their current face-to-face courses to an online format, under a time frame that did not allow for a "well-designed" online course. The current study investigates how some instructors were able to maintain social presence in the transition to the online environment, and the instructional practices they used to support those continued connections. In a cross-sectional survey of undergraduate and graduate students $(\mathrm{N}=432)$ conducted during the last week of the Spring 2020 semester, we asked students to focus on a class that was successful in keeping them in touch with their instructor, content, and peers. Analyses of the data revealed four major themes: connectedness, instructor responsiveness and coaching, online learning best practices such as chunking materials, and empathic facilitation.
\end{abstract}

Keywords: Instructor social presence, connectedness, social presence, online learning, remote teaching

Conklin, S. \& Garrett Dikkers, A. (2021). Instructor social presence and connectedness in a quick shift from face-to-face to online instruction. Online Learning, 25(1), 135-150. https://doi.org/10.24059/olj.v25i1.2482

\section{Instructor Social Presence and Connectedness in a Quick Shift from Face-to-Face to Online Instruction}

The current study investigates instructor social presence in a semester that was interrupted by an emergency transition to online learning due to the COVID-19 pandemic. Moving from the face-to-face to an online environment can be a difficult transition for instructors who may have never taken online courses and may have only taught face-to-face. This transition requires instructors to move from a teacher-centered role to a learner-centered role or facilitator (Sammons, 2003). Moving from the "sage on the stage" to a facilitator role requires support and training (Kim \& Bonk, 2006). The management of time with relation to both facilitation (e.g., being available 24/7) and course design can prove difficult for newcomers to online teaching (Smith et al., 2002), particularly given the short timeline required by an emergency transition. 
Our study is centered in an understanding of instructor social presence. Researchers have been working to decipher instructor social presence for almost two decades and have found that students value instructors who are caring, responsive, and establish a method of communication between themselves and the students (Hodges \& Cowan, 2012; Sheridan \& Kelly, 2010; Wise et al., 2004; Whiteside, 2015). In an online course, it is particularly crucial for the instructor to establish instructor social presence (Anderson et al., 2001; Mandernach, et al., 2006; Wise, et al., 2004). As discussed in the literature review below, many researchers have tried to define instructor social presence, but few researchers have attempted to define instructor social presence from the students' perspectives (Sheridan \& Kelly, 2010). In this study, we take a closer look at how instructor social presence is experienced from the student perspective during an emergency transition to online learning.

\section{Review of Related Literature}

\section{Teaching Presence and the Community of Inquiry}

Research has noted the instructor's crucial role in online course facilitation to establish teaching presence (Berge, 2008; Mandernach et al., 2006; Wise et al., 2004). Within the context of traditional asynchronous online instruction, the instructor's role becomes facilitative; rather than providing direct instruction via lecture, instructors provide resources, tools, and personal support to help students learn (Richardson \& Swan, 2003). To help describe the nature of student to instructor interaction in online learning environments, Anderson and colleagues (2001) defined the construct of teaching presence within the Community of Inquiry model (CoI). CoI is a communication and interaction framework designed to support the learning process, help students achieve higher-order critical thinking skills, and create a community of students and teachers in computer-mediated distance learning environments (Garrison \& Arbaugh, 2007). The focus of the $\mathrm{CoI}$ is to facilitate critical reflection on the part of the student and critical discourse among the instructor and peer students (Garrison et al., 2001). Grounded in specific philosophical and epistemological assumptions, and learning theories, CoI aims to encourage higher-order cognitive processing through a collaborative/constructivist environment (Garrison, 2011).

There are three essential elements to CoI: social, cognitive, and teaching presence (Garrison et al., 2001). Social presence captures the extent to which the teacher or students are able to project their true selves to the community; cognitive presence captures the extent to which the teacher or students are able to construct meaning; and teacher presence captures the instructor's instructional and pedagogical approaches. If designed in balance, these three types of presence create a collaborative environment of a community of learners (Akyol \& Garrison, 2008). Teaching presence is directly related to social and cognitive presence through the course design, facilitation, and direction. Through these three categories, students can reach meaningful and educational outcomes (Anderson, et al., 2001). Both the design and the delivery (facilitation) are interrelated and require effective responsiveness in developing needs and events. Design and organization refer to the macro-level structure of the course. Facilitating reflection and discourse develops cognitive understanding in a positive environment and involves pedagogical, interpersonal, and organizational skills. Direct instruction contradicts being a "guide on the side" but is needed to diagnose misconceptions and bring expertise to the class (Garrison \& Akyol, 2013). Teaching presence is essential for perceived learning and satisfaction (Akyol et al., 2009;

Richardson \& Swan, 2003; Swan \& Shih, 2005) and the development of a community (Brook \& 
Oliver, 2007; Ice et al., 2007; Shea et al., 2006). In this study, we focus on the overlap between an instructor's teaching presence and social presence, or instructor social presence.

\section{Instructor Social Presence}

Garrison and colleagues (2001) defined social presence as participants' ability to project their "self" into an online community and be perceived by others as real. Creating social presence within online courses requires deliberate planning on the instructor's part to ensure the learning environment promotes probing questions, skepticism, and the contribution of ideas. Within social presence are three broad categories: affective communication, open communication, and group cohesion (Rourke et al., 2001). Affective communication is primarily text-based, which includes emoticons, capitalization or punctuation, self-disclosure, or the use of humor. Recognizing, complementing, and responding to others' questions and contributions is referred to as open communication. Open communication is directly linked to group cohesion, where the participants identify with a group through the use of names and inclusive pronouns. Studies have shown a connection between social presence and student satisfaction (Akyol et al., 2009; Arbaugh \& Benbunan-Fich, 2006; Richardson \& Swan, 2003). Whiteside (2015) expanded on Rourke and colleagues' (2001) social presence coding scheme in a longitudinal qualitative study that measured social presence of two cohorts of an online certificate graduate program and identified two new elements that contributed to levels of social presence in a course: Knowledge and Experience (preknowledge and prior experiences students bring to the learning environment) and Instructor Involvement (actions the instructor takes in a learning environment, specifically around building community). Whiteside's study broadened the focus on social presence to explicitly include the instructor's actions in the course.

\section{Establishing and Maintaining Instructor Social Presence}

Recent research has identified aspects important to establishing instructor social presence from the student perspective. Sheridan and Kelly (2010) found students highly valued clear and explicit course requirements and timeliness of the instructor's response to questions and concerns. Mandernach et al., (2006) stated that instructors need to be aware of students' needs and display empathy. Often the attributes associated with instructor social presence go beyond facilitation practices and include design attributes (e.g., organization and clarity).

Specifically, regarding communication in the online classroom, Pallof and Pratt (2003) stated that an instructor's presence focuses on posting regularly to the discussion board and timely responses to emails and assignments through modeling good online communication and interactions. Kassinger (2004) defined instructor presence as the interaction and communication style along with the frequency of the instructor's input into the class discussions and communications. Martin et al., (2018) defined instructor presence as "having perceived authenticity among a community of learners and validating one's personal identity by formally acknowledging and conducting their role through various strategies" (p. 53). Martin and colleagues (2018) found students highly rated timely responses to questions and feedback on assignments. These results support previous researchers' findings that students value timely feedback as it assists their learning process (Eskey \& Schulte, 2010; King, 2014; Skramstad, Schlosser, \& Orellana, 2012).

Many researchers focus on technology tools, particularly those found in Learning Management Systems (LMS) such as discussion boards, announcements, assignment feedback (Mandernach et al., 2006; Martin et al., 2018). Mandernach and colleagues (2006) analyzed the 
instructor's number of discussion posts to determine instructor social presence. Other outside tools, such as video feedback to assignments, have been researched to establish instructor social presence (Borup et al., 2014). Borup and colleagues (2014) analyzed student reactions to video feedback on assignments. The instructor and student interviews analysis indicated there was no significant difference between the perceptions of the students who received and did not receive video feedback, although those students who did receive video feedback felt the instructors were able to convey emotion.

In general, instructional practices that support instructor social presence include posting regularly to the discussion board, timely responses to emails and assignments, and modeling good online communication and interactions (Paloff \& Pratt, 2003; Kassinger, 2004; Martin et al., 2018; Whiteside et al., 2017). Additionally, timely responses to questions and feedback on assignments have been deemed important to students as well as video introductions (Martin et al., 2018; Whiteside et al., 2017).

\section{Contribution of this Study}

Research has found that instructor presence relates to student success and satisfaction in online courses (Brinkerhoff \& Koroghlanian, 2007), enhances student motivation to learn, and reduces a feeling of isolation (Richardson et al., 2015). As more courses and programs move to an online format, understanding how students connect to instructors from the student perspective is vital for student learning and satisfaction. Since many of the students in this study were enrolled in face-to-face instruction that was forced online due to COVID-19, their responses provided insight into what students truly value in the online sphere regarding successful online courses and why they valued one aspect over another. The results from this research can assist new and seasoned instructors with recommendations for connecting with students at a distance.

Three main research questions guided the current study.

1. Which aspects of courses were deemed successful by students as keeping them connected to their instructor, content, and peers?

2. Which instructional practices were deemed most important for their satisfaction in the course that shifted to an online learning environment?

3. What recommendations can be made for faculty new to online learning or shifting faceto-face classes to an online environment to build community and connectedness in their classes?

\section{Methods}

The current study utilized a pragmatic worldview, one that is problem-centered and oriented toward real-world practice (Creswell, 2009). Researchers were seeking to understand student perceptions of connectedness in classes that shifted to remote instruction. A cross-sectional survey design, used to make inferences about a population at a certain point in time, was utilized with a mix of open- and closed-ended questions which provided an opportunity to generalize results to the larger student population (Sedgwick, 2014).

The survey was administered to a representative sample of undergraduate and graduate students at a southeastern university in the United States of America at the close of the semester, after the traditional student evaluation period ended. This university moved all face-to-face courses 
to an online format, primarily asynchronous, as a result of the COVID-19 pandemic. The survey was sent to a sample of 6,000 students compiled by the institution's Office of Institutional Research. There was a response rate of $7 \%(\mathrm{~N}=432)$. The low response rate could be attributed to the timing of the survey, which was sent at the end of the semester. Although students were asked to focus on successful courses, there were responses that indicated frustration with the university going online, no refunds in tuition, and instructors who were non-responsive during remote teaching. The frustration of the students could be a main reason that students did not respond as they were ultimately done with the semester once they completed the course evaluations. In addition to the low response rate, many students began but did not complete the survey. Although there was a $7 \%$ response rate for the open-ended questions, students dropped off by half in the closed-ended questions.

Overall, respondents were $22 \%$ male and $73 \%$ female, and $5 \%$ who indicated another gender, preferred not to say, or skipped the question; in terms of program, $82 \%$ were undergraduate, $13 \%$ master's degree students, and $2 \%$ in other post-degree programs; in terms of age, $74 \%$ were aged 18 to $24,12 \%$ aged 25 to 34 , and $11 \%$ aged 35 or older. Respondent demographics align with overall student population at the institution. Respondents were overwhelmingly female; however, this matches the institution demographics for 2019-2020 with our overall undergraduate population as $63 \%$ female and $37 \%$ male. Additionally, $81 \%$ of the respondents were undergraduate, which matches the institution demographics of $84 \%$ undergraduate, $16 \%$ graduate. In terms of course discipline, most students reported on courses from the College of Arts and Sciences, including courses in the sciences (22\%), humanities (21\%), and social sciences $(17 \%)$. Other courses were in the areas of business $(11 \%)$, health and human services (9\%), and education (6\%). Overall, every college/school in the University was represented in the survey.

The survey instrument contained five basic demographic questions and three open-ended questions to reflect the change of instructional method from face-to-face to online. Students were asked to 1) identify a face-to-face course that transitioned to online, 2) provide examples of why they thought the course was successful, and 3) provide additional information they wanted to share. The remainder of the instrument contained thirteen closed-ended questions adopted from Sheridan and Kelly (2010) which tapped students' perceptions of instructor social presence. Some closedended questions on the survey utilized a Likert scale from 1-4 (strongly agree to strongly disagree). Other questions asked students to rank items from most important to least important. While students may not be fully qualified to answer questions about objective teaching quality, we were specifically seeking to understand students' perceptions.

Data analysis techniques included descriptive statistics for closed items on the survey, as well as established and emergent coding of qualitative responses from the survey open-ended questions. Established codes were based on Sheridan and Kelly's (2010) code book, specifically Instructor Social Presence and the Social Presence Model (Whiteside, 2015). The research team took several steps to check for accuracy and reliability of findings. First, both researchers read through all of the open-ended responses to gain an overall sense of the data. Second, the researchers individually analyzed a sample of open-ended responses from the survey and, in a series of meetings, met for consensus agreement (Creswell, 2009). Throughout the coding process for all open-ended survey data, the two researchers met regularly to cross-check codes and share their analysis, another measure to establish reliability of the research findings. The emerging codes of Design (e.g., clarity of assignments and due dates) and Instructional Practices (e.g., methods of 
communicating with the students) were added. The final code book was organized around the main areas of Design, Instructional Practices, Instructor Social Presence, and the Social Presence Model.

\section{Results}

In the following section, we present the analysis of the results along with a discussion of key findings. The pragmatic focus to understand student perceptions at a time when students were dispersed away from campus meant that open-ended questions provided key data. In fact, the openended questions received the most responses on the survey, while closed-ended question response rates varied; the qualitative data is central to our discussion of results, with the quantitative data providing further support and detail. Four large themes emerged across both open- and closedended questions: connectedness, instructor responsiveness and coaching, online learning best practices such as chunking materials, and empathic facilitation.

\section{Connectedness}

Student responses on open- and closed-ended questions supported the importance of feeling connected to their instructor, class, and classmates. When asked to rank methods of communication in terms of importance to their learning and motivation-including text announcements, video announcements, course emails, or a mix of text and video - most students $(67 \%)$ ranked course emails as most important. One representative comment shared by a student explained "

Our professor sent us emails for each class period along with additional emails with reminders, all of which served to thoroughly but concisely explain what we needed to do, when we needed to do it by, and where instructions were located on Canvas.

Students were also asked to rank their preferred methods to connect with their instructors and get a sense of the instructor's self or personality, with 1 being the top rank and 4 being the bottom rank. (See Table 1).

\section{Table 1}

Preferred Methods to Connect with Instructors

\begin{tabular}{lcccc}
\hline & N & $\begin{array}{c}\text { Mean } \\
\text { Rank }\end{array}$ & $\begin{array}{c}\text { Std. } \\
\text { Deviation }\end{array}$ & $\begin{array}{c}\text { Ranked } \\
\text { Created instructional videos to explain course }\end{array}$ \\
$\begin{array}{l}\text { content using PPT } \\
\text { Used a conversational tone when writing }\end{array}$ & 209 & 1.71 & 0.92 & $56 \%$ \\
$\begin{array}{l}\text { Provided video feedback on assignments } \\
\text { Created informal "announcement" videos }\end{array}$ & 209 & 3.35 & 0.83 & $4 \%$ \\
\hline
\end{tabular}


As shown in Table 1, most students (56\%) rated instructor-created videos as most important to connecting with the instructor. In open-ended responses, students mentioned these videos 67 times. One student stated, "The teacher uploaded video lectures, which seems like it made his communication with us more easily understandable than just text posts." Another student stated, "The class was almost exactly like being there. The professor provided video lectures where we could also see her."

Regarding the use of conversational tone while writing, students mentioned ways their instructors "kept in touch", such as with "kind messages" over email, discussion boards set up just as a space for classmates to stay in contact with each other and the instructor, or informal weekly check-ins via Zoom. A student explained, "She constantly was email us saying, 'it's okay to be frustrated, it's okay to feel upset, but we're going to do this together." Another student stated, "She was very warm and genuine in her emails which made me feel closer to her and the class."

Other instructors used humor to reduce anxiety, with one student explaining, "She kept the course light with humor and I still feel like I learned a lot and wasn't a major source of stress like other classes were." Another student stated, "His charisma and overall sense of humor could be acquired as if we were in the actual classroom."

\section{Instructor Responsiveness}

Students used the terms responsive and accessible interchangeably. Students valued being able to contact their instructors, having timely responses to inquiries, and receiving regular reminders of due dates. For example, one student stated, "[The] professor consistently reached out and offered opportunities to talk and ask questions." Another student stated, "My instructor would email back very fast, answer any of my questions, and also continuously sent out weekly announcements to address what was due at the end of the week." When asked to rank five expectations about instructor response time from most to least important, $68 \%$ of student respondents identified it was most important for instructors to respond to student questions or concerns within 12 to 24 hours, with the majority indicating it was important to receive a response within 12 hours (see Table 2). This theme was also mentioned in the qualitative data 61 times.

For example, a student stated, "I was able to communicate with my instructor whenever I wanted, and was able to continue the class in a very similar way as we did before." Another student stated, "They also were extremely prompt with responding to emails and posting graded assignments." Students overall were very appreciative of the quick turnaround time to email questions, such as the student who shared, "She also emailed frequently and made sure to respond within 24 hours. In most cases I usually had a response within 12 hours." Although many of the students did not reference a turnaround time, the most used phrase with email response time was "timely manner" (mentioned 21 times) indicating satisfaction with the response time. 
Table 2

Descriptives and Frequency of Student Preferred Response Time from the Instructor

\begin{tabular}{|c|c|c|c|c|}
\hline & $\mathbf{N}$ & $\begin{array}{l}\text { Mean } \\
\text { Rank }\end{array}$ & $\begin{array}{l}\text { Std. } \\
\text { Deviation }\end{array}$ & $\begin{array}{c}\text { Ranked } \\
\quad \# 1\end{array}$ \\
\hline $\begin{array}{l}\text { Responded to student questions or concerns } \\
\text { within } 12 \text { hours }\end{array}$ & 218 & 1.77 & 1.01 & $51 \%$ \\
\hline $\begin{array}{l}\text { Responded to student questions or concerns } \\
\text { within } 24 \text { hours }\end{array}$ & 218 & 2.27 & 0.82 & $17 \%$ \\
\hline $\begin{array}{l}\text { Responded to student questions or concerns } \\
\text { within } 48 \text { hours }\end{array}$ & 218 & 3.39 & 0.78 & $3 \%$ \\
\hline $\begin{array}{l}\text { Responded to students questions or concerns } \\
\text { within } 72 \text { hours }\end{array}$ & 218 & 4.51 & 0.69 & $<1 \%$ \\
\hline Made the response time known in the syllabus & 218 & 3.06 & 1.67 & $28 \%$ \\
\hline
\end{tabular}

\section{Empathic Facilitation}

An area many students referenced was empathic facilitation, or demonstrating an understanding of others' situations through processes and practices in the course. Students highly valued instructors who reached out via email or announcements, noted an understanding of the situation, and otherwise demonstrated they cared about the students, the situation, and student learning. One student mentioned that, "My instructors were very accommodating and understood students were having to homeschool their own children while trying to complete their own graduate work and work from home (employment)." Another student stated, "She was extremely understanding and helpful. She wanted us to succeed and still understand the material but knew that we were facing a lot of changes and stressors." One student made a reference to the instructor's empathy stating, "[He] often told us about taking care of ourselves first. In other words he was sympathetic and caring." The following student quote demonstrates a focus on the positivity of instructors during difficult times.

I thought this course was successful because there was constant communication, encouragement, positivity and updates regarding assignments as well as just being positive. For example, our teacher would email us before the assignment was posted with information, told us how long the assignment would take and for how long it was up. After she communicated with us the day or night before she would post the assignment and email again to let us know to do it and then would start every week with an update on life (positively) and describing the week to come.

Another student mentioned her instructor's sincerity:

She was very understanding with me personally when I had internet issues and assured me and other students that it would not negatively affect our success in the class. She was quick to make adjustments to exams when we communicated issues with the online format. She quickly replied to emails with concerns and was greatly encouraging and 
remained positive throughout the situation. She made a discussion board where we could talk about issues we were facing and she personally read and responded to each of us. I feel like she genuinely cared about our success in the course, and did not give up on its instruction.

When asked about the feelings an instructor can create in an online course, and the extent to which these feelings are important to learning or motivation, participants tended to strongly agree (1) or agree (2) that the feelings listed in Table 3 are important. In open-ended questions, students referred to these feelings when asked about additional characteristics of instructor social presence. Students mentioned the word "care[ing]" eleven times and "understand[ing]" twentynine times in the open-ended questions. For example, one student stated, "She expressed her care for students and emailed us on a weekly basis to discuss what our schedule for the week would be." Another student noted the instructor "genuinely cares about everyone's education and wants us all to succeed." A third student mentioned both, stating, "He was caring and understanding, and was always available for questions, despite having so much going on himself."

\section{Table 3}

Statements Regarding the Feeling the Instructor Creates in the Course Central to Student Learning and Motivation

\begin{tabular}{|c|c|c|c|c|}
\hline & $\mathbf{N}$ & Mean & Std. Deviation & $\begin{array}{c}\text { \% Agree or } \\
\text { Strongly } \\
\text { Agree }\end{array}$ \\
\hline $\begin{array}{l}\text { Creates a feeling of trust and } \\
\text { acceptance }\end{array}$ & 243 & 1.35 & 0.58 & $69 \%$ \\
\hline $\begin{array}{l}\text { Creates a feeling of community } \\
\text { among the students }\end{array}$ & 242 & 1.60 & 0.76 & $54 \%$ \\
\hline $\begin{array}{l}\text { Creates a feeling of community with } \\
\text { the instructor }\end{array}$ & 243 & 1.47 & 0.68 & $61 \%$ \\
\hline Makes me feel good about myself & 244 & 1.61 & 0.73 & $51 \%$ \\
\hline $\begin{array}{l}\text { Gives me a sense of belonging in } \\
\text { the course }\end{array}$ & 244 & 1.50 & 0.72 & $61 \%$ \\
\hline
\end{tabular}

Based on the data, to create a feeling of trust and acceptance and a community, the instructor must show a high degree of empathy towards students' learning. During the pandemic, displaying an understanding of the various difficult situations such as working full-time while caring for children were rated high by the students.

\section{Online Teaching Best Practices}

Students identified multiple teaching practices that are considered to be online teaching best practices. Qualitative responses signified students valued clear organization of content and 
course sites. Students mentioned the term "organized" sixteen times. Although they did not describe what they meant by organized, the instructor being organized was very important to their success. For example, one student stated, "[the professor] organized everything in a way that was easy to understand." Another student stated, "The organization from my teacher and the simplicity/straightforwardness of the course layout made the transition smooth." Another student stated, "The content was very organized and not all over the place." Finally, another student provided insight into organization, the instructor "kept Canvas very organized and in each weekly module I could find all the assignments that were due that week."

It also seems that students appreciated instructors who provided additional clarity of due dates as this was addressed by students thirty times in the open-ended questions. For instance, a student wrote, "She would send us a weekly email wishing us good health and an organized list of what's to be done in the week. I appreciate her being calm and helpful during this time." Another student stated, "This course was successful because my professor always emailed us about due dates and always gave us a heads up when an assignment opened."

When asked to rank methods of feedback in terms of importance to their learning and motivation-including substantial constructive feedback that was text-based, positive feedback that was text-based, substantial constructive feedback that was audio/video based, positive feedback that was audio/video based, or a grade provided with minimal constructive feedbackmost respondents (62\%) ranked substantial, constructive, text-based feedback as most important. Students were also asked to rank ways that their instructor could project their "self" or "personality" in terms of importance to their learning and motivation-including creating instructional videos to explain course content, using a conversational tone when writing, providing video feedback on assignments, and creating informal "announcement" videos. Most respondents $(56 \%)$ felt it was most important for instructors to create videos to explain course content. When asked about how an instructor facilitates the course overall, and the extent to which these approaches are important to learning or motivation, participants tended to strongly agree (1) or agree (2) that the approaches listed in Table 4 are important.

\section{Table 4}

Statements Regarding Course Facilitation Central to Student-Perceived Learning and Motivation

\begin{tabular}{|c|c|c|c|c|}
\hline & $\mathbf{N}$ & Mean & $\begin{array}{c}\text { Std. } \\
\text { Deviation }\end{array}$ & $\begin{array}{l}\text { \% Agree or } \\
\text { Strongly } \\
\text { Agree }\end{array}$ \\
\hline $\begin{array}{l}\text { Helps in identifying areas of agreement and } \\
\text { disagreement on course topics that helps me to } \\
\text { learn }\end{array}$ & 242 & 1.56 & 0.69 & $53 \%$ \\
\hline $\begin{array}{l}\text { Helps in guiding the class towards understanding } \\
\text { course topics in a way that helps me clarify my } \\
\text { thinking }\end{array}$ & 243 & 1.42 & 0.68 & $66 \%$ \\
\hline $\begin{array}{l}\text { Helps keep the course participants on task in a } \\
\text { way that helps me to learn }\end{array}$ & 242 & 1.52 & 0.73 & $58 \%$ \\
\hline
\end{tabular}


In addition, students mentioned valuing shifts instructors made by changing assessments such as cumulative tests to short answers, or incorporating reflections or materials that were authentic to the learning context. One student stated their instructor "converted the tests to being researchbased and gave us a couple of days for each of them, which was effective." Another student described the changes to assignments as:

We were supposed to have debates in class and did not get the chance. Luckily, the debates turned into discussion boards where you had to pick a side of the argument and respond to other people who you agreed/ disagreed with. It allowed me to understand the material better and was a fun way to have a form of contact with my peers.

Yet another student stated,

He provided ... video instructions for things we did not cover in class (example: we were supposed to do in class role plays but obviously we were not able to do that face to face given the circumstances. He provided a video tutorial on how he wanted the project to be done in the new format with new technology).

Although course design aspects were not addressed in the closed-ended questions, students mentioned them as part of being a successful course. Overall, creating an organized structure, where students have an understanding of what is to be completed, along with clear due dates, was very important to their learning process.

\section{Implications and Recommendations}

This study has implications for instructors and instructional designers, as well as considerations for institutions as a whole when shifting to emergency remote teaching. The results of this study recommend connecting with online students through multiple tools, responding in a timely manner, and integrating empathic facilitation within messages either through video, synchronous contact, or text. Although this study did not focus on online course design, students highly value instructors who are organized and provide clarity of assignments and due dates.

The primary recommendation emerging from the current study is for instructors to use multiple methods to connect with students (Martin et al., 2018; Sheridan \& Kelly, 2010; Whiteside, et al., 2017). Students highly value being connected with their instructor particularly through email or announcements, yet many students also stated they preferred to connect with instructors through instructional videos as well as synchronous meetings. During the shift to emergency remote teaching, our institution did not allow instructors to require synchronous meetings due to shifts in circumstances for students moving off campus or otherwise being impacted by the COVID-19 pandemic. However, students in the current study overwhelmingly valued synchronous connections with their instructors, and those who were unable to attend synchronously valued being able to watch recorded sessions and otherwise "see" their faculty members.

Giving students multiple formats for interacting with the instructor allows the diverse population to connect via their preference. Also, various tools allow the instructor to connect with students on different timeframes. For example, an asynchronous video is on-demand and the student can access it immediately, yet for a question via email a student may have to wait 12-14 hours, and for substantive feedback on assignments, students may have to wait up to one week. The delivery mode of the message varies among students, but students valued the message no matter the mode of delivery (e.g., video, email, announcement). 
Students highly valued instructors who gave the perception they cared about the students and their learning. This idea of the importance of demonstrating care is widely supported through the literature on instructor social presence (Sheridan \& Kelly, 2010; Whiteside, 2015; Whiteside et al., 2017). Empathic messages can be created during the course design process. For example, during the instructor introduction video or welcome text, instructors can let students know that "life happens" and to be sure to communicate with them. Even during non-COVID times, many students hold full-time employment or have children. These types of messages can also be integrated into weekly emails or announcements. Within messages (video or text), instructors should convey the message, "I am here with you on your learning journey." This can be done via email, announcement, instructional videos, etc. For example, an instructor could state, "I realize this content is difficult; please let me know if you have questions." Reassuring students frequently sends the message of caring and understanding.

Students also valued timely feedback (within $12-24$ hours). The expectation from students of an almost immediate turnaround to inquiries could be because these classes were face-to-face before COVID-19 and most met two or three times a week. Students had access to their teachers regularly in the face-to-face classes and it seems as though that expectation or desire carried over into the remote classes. However, students also stated that is it important to make the instructor response time known on the syllabus. When creating syllabi for courses, be sure to specify the response time to both email and assignment feedback as the transparency lessens students' anxiety (Abdous, 2019). Strategies for instructors to respond in a timely manner include creating a schedule that sets time aside for facilitation (Martin et al., 2020). In online learning, a common issue is students not understanding an assignment or completing early assignments incorrectly, which may impact future assignments in the course. Providing early and iterative feedback is crucial (Whiteside et al., 2017). Additional strategies include creating a frequently asked questions page that students can read, re-using feedback comments, providing collective feedback to the class highlighting individual students, and using various modalities to provide feedback (Martin et al., 2020).

Although recent research discusses the value of video feedback and video announcements for instructor presence (Borup et al., 2015), students within this study specifically valued instructor-created videos for content delivery. Connecting through instructional video may give students the feeling of attending class and being with the instructor. Creating a personalized feeling of being with or near the instructor supports research set forth by Berge (2008) under the pedagogical construct of the instructor facilitation model. Berge (2008) identified the functions of instructors in four categories: pedagogical, social, managerial, and technical. Creating a video may prove difficult for the novice instructor, but recommendations for new instructors would be to start small. Begin with an instructor introduction and a course overview. Over time, begin to add instructional videos of content that needs to be disseminated, not discussed. These types of instructional videos can be utilized for both face-to-face and online courses. In the face-to-face courses, instructors can use instructional videos to flip the class (i.e., have students watch a lecture outside of class) and utilize in-class time for problem based learning or other hands-on activities or group work.

In addition, students appreciated conversational tone in written text, which kept them connected to their instructor. This distinction may be important for novice online instructors who may feel overwhelmed with the thought of using video for announcements or feedback. Students in this study appreciated the use of humor and the realization that their instructor was "human". 
This focus on the affective aspects of teaching and learning (Rourke et al., 2001; Swan, 2002; Whiteside, 2015; Whiteside, 2017) supports students in building community and connecting in the online space.

Students mentioned seamless transitions in cases where their face-to-face class already utilized the learning management system for assignment submission, discussion boards, or even as a repository for course materials. In an environment where it is uncertain if a class can continue in its scheduled face-to-face modality, whether due to COVID-19 or natural disasters such as hurricanes or wildfires, faculty who build their class space in the LMS from the beginning may be seen as more successful in a shift.

The strategies listed above for online instructors would also apply to instructional designers. Typically, instructional designers collaborate with instructors on course design, but as this study has demonstrated, facilitation strategies are equally important to a well-designed class. The findings suggest instructional designers inform instructors of various facilitation strategies and help instructors build these strategies into their course design. 


\section{References}

Abdous, M. H. (2019). Influence of satisfaction and preparedness on online students' feelings of anxiety. The Internet and Higher Education, 41, 34-44.

Akyol, Z., \& Garrison, D. R. (2008). The development of a community of inquiry over time in an online course: Understanding the progression and integration of social, cognitive and teaching presence. Journal of Asynchronous Learning Networks, 12, 3-22. http://dx.doi.org/10.24059/olj.v12i3.66

Akyol, Z., Garrison, D. R., \& Ozden, M. Y. (2009). Online and blended communities of inquiry: Exploring the developmental and perceptual differences. The International Review of Research in Open and Distributed Learning, 10(6), 65-83.

Anderson, T., Liam, R., Garrison, D. R., \& Archer, W. (2001). Assessing teaching presence in a computer conferencing context. Journal of Asynchronous Learning Networks, 5(2). http://dx.doi.org/10.24059/olj.v5i2.1875

Benbunan-Fich, R., \& Arbaugh, J. B. (2006). Separating the effects of knowledge construction and group collaboration in learning outcomes of web-based courses. Information \& Management, 43(6), 778-793.

Berge, Z. (2008). Changing instructor's roles in virtual worlds. Quarterly Review of Distance Education, 9(4), 407-415. https://www.learntechlib.org/p/106706

Borup, J., West, R. E., Thomas, R. A., \& Graham, C. R. (2014). Examining the impact of video feedback on instructor social presence in blended courses. International Review of Research in Open and Distributed Learning, 15(3), 232-256. http://dx.doi.org/10.19173/irrodl.v15i3.1821

Brook, C., \& Oliver, R. (2007). Exploring the influence of instructor actions on community development in online settings. In User-centered design of online learning communities (pp. 341-364). IGI Global. http://dx.doi.org/10.4018/978-1-59904-358-6.ch015

Creasey, G., Jarvis, P., \& Knapcik, E. (2009). A measure to assess student-instructor relationships. International Journal for the Scholarship of Teaching and Learning, 3(2), n2. http://dx.doi.org/10.20429/ijsotl.2009.030214

Creswell, J.W. (2009). Research design: Qualitative, quantitative, and mixed method approaches. London and Thousand Oaks: Sage Publications.

Eskey, M.T., \& Schulte, M. (2010). What online college students say about online instructors and what do online faculty members say about online instructions: A comparison of attitudes. Journal of Online Education, 1-20.

Hodges, C.B., \& Cowan, S. F. (2012). Preservice teachers' views of instructor presence in online courses. Journal of Digital Learning in Teacher Education, 28(4), 139145. http://dx.doi.org/10.1080/21532974.2012.10784694

Garrison, D. R. (2011). E-learning in the 21st century: A framework for research and practice. Taylor \& Francis.

Garrison, D. R., \& Akyol, Z. (2013). The community of inquiry theoretical framework. Handbook of distance education, 3, 104-120. 
Garrison, D. R., \& Arbaugh, J. B. (2007). Researching the community of inquiry framework: Review, issues, and future directions. The Internet and Higher Education, 10(3), 157172. http://dx.doi.org/10.1016/j.iheduc.2007.04.001

Garrison, D. R., Anderson, T., \& Archer, W. (2001). Critical thinking, cognitive presence, and computer conferencing in distance education. American Journal of Distance Education, 15(1), 7-23. http://dx.doi.org/10.1080/08923640109527071

Ice, P., Curtis, R., Phillips, P., \& Wells, J. (2007). Using asynchronous audio feedback to enhance teaching presence and students' sense of community. Journal of Asynchronous Learning Networks, 11(2), 3-25. http://dx.doi.org/10.24059/olj.v11i2.1724

Kassinger, F. D. (2004). Examination of the relationship between instructor presence and the learning experience in an asynchronous online environment (Doctoral dissertation). http://scholar.lib.vt.edu/theses/available/etd-12232004230634/unrestricted/Kassingeretd.pdf

Kim, K. J., \& Bonk, C. J. (2006). The future of online teaching and learning in higher education. Educause Quarterly, 29(4), 22-30.

King, S. B. (2014). Graduate student perceptions of the use of online course tools to support engagement. International Journal for the Scholarship of Teaching and Learning, 8(1). http:doi.org/10/20429/ijsotl.2014.080105

Mandernach, B. J., Gonzales, R. M., \& Garrett, A. L. (2006). An examination of online instructor presence via threaded discussion participation. Journal of Online Learning and Teaching, 2(4), 248-260

Martin, F., Wang, C., \& Sadaf, A. (2018). Student perception of helpfulness of facilitation strategies that enhance instructor presence, connectedness, engagement and learning in online courses. The Internet and Higher Education, 37, 52-65. http://dx.doi.org/10.1016/j.iheduc.2018.01.003

Martin, F., Wang, C., \& Sadaf, A. (2020). Facilitation matters: Instructor perception of helpfulness of facilitation strategies in online courses. Online Learning, 24(1), 28-49. http://dx.doi.org/10.24059/olj.v24i1.1980

Palloff, R. M. \& Pratt, K. (2003). The virtual student. A profile and guide to working with online learners. Jossey-Bass.

Richardson, J., \& Swan, K. (2003). Examining social presence in online courses in relation to students' perceived learning and satisfaction. Journal of Asynchronous Learning Networks, (7)1,68-88.

Sammons, M. (2003). Exploring the new conception of teaching and learning in distance education. Handbook of Distance Education, 387-397.

Sedgwick, P. (2014). Cross sectional studies: Advantages and disadvantages. BMJ, 348, g. 2276. http://dx.doi.org/10.1136/bmj.g2276

Shea, P., Li, C. S., \& Pickett, A. (2006). A study of teaching presence and student sense of learning community in fully online and web-enhanced college courses. The Internet and Higher Education, 9(3), 175-190. http://dx.doi.org/10.1016/j.iheduc.2006.06.005 
Sheridan, K., \& Kelly, M.A. (2010). The indicators of instructor presence that are important to students in online courses. Journal of Online Learning and Teaching, 6(4), 767-779.

Skramstad, E., Schlosser, C., \& Orellana, A. (2012). Teaching presence and communication timeliness in asynchronous online courses. Quarterly Review of Distance Education, 13(3), 183.

Smith, G. G., Ferguson, D., \& Caris, M. (2002). Teaching on-line versus face-to-face. Journal of Educational Technology Systems, 30(4), 337-364. http://dx.doi.org/10.2190/FFWX-TJJE5AFQ-GMFT

Swan, K. (2002). Building learning communities in online course: The importance of interaction. Education, Communication, and Information, 2(1), 23-49. http://dx.doi.org/10.1080/1463631022000005016

Swan, K., \& Shih, L. F. (2005). On the nature and development of social presence in online course discussions. Journal of Asynchronous Learning Networks, 9(3), 115-136. http://dx.doi.org/10.24059/olj.v9i3.1788

Whiteside, A. L. (2015). Introducing the Social Presence Model to explore online and blended learning experiences. Online Learning, 19(2). http://dx.doi.org/10.24059/olj.v19i2.453

Whiteside, A. L. (2017). Understanding social presence as a critical literacy: Introduction to part four. In A. L. Whiteside, A. Garrett Dikkers, \& K. Swan (Eds.) Social presence in online learning: Multiple perspectives on research and practice (pp. 133-142). Stylus Publishing, LLC.

Whiteside, A. L., Garrett Dikkers, A., \& Lewis, S. (2017). Overcoming isolation online: Strategies to enhance social presence in practice. In A. L. Whiteside, A. Garrett Dikkers, \& K. Swan (Eds.) Social presence in online learning: Multiple perspectives on research and practice (pp. 180-187). Stylus Publishing, LLC.

Wise, A., Chang, J., Duffy, T., \& del Valle, R. (2004). The effects of teacher social presence on student satisfaction, engagement, and learning. Journal of Educational Computing Research, 31(3), 247-271. http://dx.doi.org/10.2190/V0LB-1M37-RNR8-Y2U1 